\title{
Ghana in the Face of COVID-19: Economic Impact of Coronavirus (2019-NCOV) Outbreak on Ghana
}

\author{
Randy Amponsah ${ }^{\circledR}$, Isaac Atta Frimpong \\ Yangtze University, Jingzhou, China \\ Email: ramponsah17@gmail.com
}

How to cite this paper: Amponsah, R., \& Frimpong, I. A. (2020). Ghana in the Face of COVID-19: Economic Impact of Coronavirus (2019-NCOV) Outbreak on Ghana. Open Journal of Business and Management, 8, 1404-1411.

https://doi.org/10.4236/ojbm.2020.84089

Received: May 3, 2020

Accepted: June 14, 2020

Published: June 17, 2020

Copyright $\odot 2020$ by author(s) and Scientific Research Publishing Inc. This work is licensed under the Creative Commons Attribution International License (CC BY 4.0). http://creativecommons.org/licenses/by/4.0/

\begin{abstract}
After the emergence of COVID-19 and subsequently being declared by the World Health Organization (WHO) as a global pandemic it has posed several effects on quality of life and other necessary areas of life on many countries. This perspective intends to update on the incidence and inform regarding COVID-19 in Ghana, and also looks at the economic effect of the global pandemic on a developing country like Ghana, with the main channel discussed being international trade.
\end{abstract}

\section{Keywords}

COVID-19, Economic Impact, Ghana, Ghanaian Economy, International Trade

\section{Background}

Wuhan, the capital city of Hubei province in the People's Republic of China (PRC) on 31 December 2019 registered the first case of a new pneumonia which origin was uncertain but now largely known as coronavirus (2019-nCoV) (Who-China-Joint-Mission-on-Covid-19-Final-Report, n.d.). This name covers the year it was discovered, and the fact that it was a novel coronavirus thus Coronavirus-related Disease 2019 (What Does COVID-19 Stand for? Meaning of Coronavirus Name-World News-Mirror Online, n.d.). The virus is caused by a Severe Acute Respiratory Syndrome Coronavirus 2 (SARS-CoV2). The COVID-19 virus is a kind of zoonotic pathogen(s) with the ability to be transmitted through humans and animals alike. Symptoms include fever, shortness of breath and cough (Addi et al., 2020). The World Health Organization (WHO) on 11 March 2020 declared COVID-19 a global pandemic (WHO Finally Declares COVID-19 a "Pandemic"/Live Science, n.d.), cases of COVID-19 have since then been on 
the rise with 1,653,204 cases and 102,088 deaths as at 11 April 2020 (Situation Update Worldwide, as of 11 April 2020, n.d.). In a bid to fight this global pandemic, countries have implemented necessary preventive and control measures including lockdowns to reduce the spread, mortality rate and in general the effect of the virus on the global economy (Qiu et al., 2017). Activities earlier have mostly been geared toward creating awareness about the cause of the disease, reporting cases of infection, treatment of the infected and engaging in medical research to come out with a cure (s) and/or vaccines (Qiu et al., 2017). Currently, most African countries including Ghana keep recording rising cases of COVID-19 (Munthali et al., 2020) which makes it daunting to look into the case of COVID-19 in Ghana. This report intends to update and inform about the incidence of COVID-19 in Ghana, and also look at the effect of the global pandemic on a major sector like international trade of a developing country like Ghana.

\section{The Current COVID-19 Status of Ghana}

Ghana is a natural resource enriched country located in the Western part of Africa, with an estimated population of 31.07 million people (50,000 Enumeration Areas Earmarked for 2020 Population Census-Business Ghana, n.d.; Ghana Population (2020) - Worldometer, n.d.). Ghana has an expected Gross Domestic Product (GDP) of 66.00 USD Billion by the end of the current quarter (Ghana Economy-GDP, Inflation, CPI and Interest Rate, n.d.; Ghana GDP Annual Growth Rate/2000-2019 Data/2020-2022 Forecast/Calendar, n.d.).

As at 12 April 2020 per the report of the Ghana Health Service (GHS) at 06:04:05 GMT+0000 (Greenwich Mean Time) the status of Ghana with respect to COVID-19 were 408 confirmed cases. And it is informed that additional numbers are being recorded through an on-going enhanced contact tracing and testing across the country. According to the GHS reports international travellers who had been under mandatory quarantine and had tested negative between March 21 and April 4 tested positive upon a second test screening. Geographically, 6 out of 16 regions (provinces) have recorded cases of the COVID-19 pandemic in Ghana with 3 cities under lockdown due to records of overwhelming cases (Enu et al., 2013; GHS, 2018; Situation Update Worldwide, as of 11 April 2020, n.d.). Considering the above stated facts, it is obvious that the Corona virus pandemic is on the rise in Ghana and mass community spread is also on the rise therefore making it an issue of no debate that the case of COVID-19 in Ghana has to be looked at. However, the most relevant thing now in the economic and health front is to mobilize resources, empower health care service providers and personnel to trace origins of the pandemic and with calculated efforts work towards its mitigation.

\section{International Trade as a Major Channel of COVID-19 Impact on Ghana}

One major channel that brings to bear the huge impact of COVID-19 on Ghana 
is that of international trade, hence needs to have a good look at it. It is well known that in the global marketplace Ghana is well integrated. The country's GDP has exports forming about $33.6 \%$ and $34.7 \%$ being importation of goods and services. This therefore suggests that international trade forms $68.3 \%$ of the total GDP of Ghana. This therefore implies that Ghana as a country has high dependence on international trade. In the area of partner share in export trade, Ghana's top partners are India (US\$3.8 billion), China (US $\$ 2.0$ billion), South Africa (US $\$ 1.7$ billion), Switzerland (US $\$ 1.6$ billion), and Netherlands (US $\$ 1.2$ billion). On the other hand, regarding imports, China (US\$3.3 billion), United States (US $\$ 1.0$ billion), Belgium (US $\$ 0.7$ billion), India (US $\$ 0.7$ billion), and the United Kingdom (US $\$ 0.6$ billion) respectively are Ghana's top 5 partners. Considering the data given it suggests that Ghana's trade with China the first country to record the outbreak of this pandemic contributes an estimated amount of about US $\$ 5.3$ billion forming about $8 \%$ of Ghana's GDP (Cooperative, 2020; Economic Impact of COVID-19 on Ghana: What Are the Channels, n.d.; Global Market Outlook Not over until It's Over, 2019).

As lockdowns have been introduced, there is a high expectation of reduction in trade, therefore translating into a decline in trade between Ghana and its trade partners leading to huge economic loss for the countries involved (Ayittey et al., 2020; Economic Impact of COVID-19 on Ghana: What Are the Channels, n.d.). Now looking at the contribution of trade with China for instance it is no doubt that the international trade channel in the face of this global pandemic presents an avenue through which the Ghanaian economy will be greatly impacted negatively. This is certainly a reason to be alarmed because unfortunately, Ghana's top 5 partners in both import and export fronts are currently disproportionately affected by COVID-19. Apart from China, the United States of America, United Kingdom, Netherlands, Switzerland and Belgium are all equally hard hit by the pandemic. With high number of infected cases and increasing death rates, stringent measures like lockdowns and other necessary trade restrictions have been introduced by these partners which will obviously make the Ghanaian economy suffer (Agyekum et al., 2015; Cooperative, 2020; Economic Impact of COVID-19 on Ghana: What Are the Channels, n.d.; Global Market Outlook Not over until It’s Over, 2019; Enu et al., 2013; Ofori-Atta, 2020; UNCTAD, 2020).

\section{COVID-19 Effect on Ghana in Another Perspective}

It is without doubt that the COVID-19 pandemic has come as a major threat on the Ghanaian economy especially on the side of international trade (Ayittey et al., 2020; Enu et al., 2013; UNCTAD, 2020). However, there have been some points and activities that can be raised to communicate a seemingly positive side of the incidence of the pandemic in Ghana. Potentials are being realised as most people have now proven and put to productive use their innovative skills and abilities. Though the pandemic in the larger sense is an unwelcomed guest, in the quest to fight the pandemic and as much as possible stay healthy and sound, 
many Ghanaians have realized their creative, inventive and innovative abilities and potentials, a major example being a shoe maker by name Richard Kwarteng who has produced an automated hand washing machine that has now caught the attention of Ghanaians and international audience as well (404-Thedistin, n.d.). Funds are being generated internally to fund the COVID-19 prevention and control response which is in line with the Ghana beyond aid agenda preached by the current government (Govt. Seeks to Lower Cap on Stabilization Fund, n.d.). Now alcoholic beverage producers like KASAPREKO have shifted to production of alcohol based hand sanitizers which is proven to be effective on surfaces and on hands. This has helped the masses stay safe and follow the basic safety precaution of sanitizing hands as much as practicable (Coronavirus: Kasapreko Halts Production of Drinks to Produce Hand Sanitizers, n.d.). Sanitation is seeing a face lift also as the empty streets and places has provided an opportunity for the ministry in charge of sanitation to embark on clean-up exercises (COVID-19 Heralds Mass Cleanup in Ghanaian Capital/Voice of America-English, n.d.).

\section{Ghana's Strategies Employed to Control COVID-19}

Following the aftermath of recent epidemics and pandemics like H1N1 and Ebola, the need to reinforce national public health systems and infrastructures coupled with good laboratory networks and disease surveillance has become core for all (WHO Ebola Response Team, 2016; GHS, 2018; Mathur et al., 2014; Ostwald, 2014). As such, in a bid to further handle and possibly mitigate the spread of the global pandemic (COVID-19) in Ghana and equally make life more safer for the citizenry the government over the past weeks put in place certain needed measures. The major step taken by the government of Ghana in the face of COVID-19 is the use of the 3T procedure (Testing, Tracing and Treatment) to help best to know people's health status and know the right line of action (COVID-19 Updates/Ghana, n.d.). In a bid to reduce the probability of importing more cases of infected persons from outside the country, the government has introduced a lockdown of all borders of the country and equally restricting as much as possible international travels (Coronavirus Travel Restrictions and Bans Globally: Updating List-The New York Times, n.d.; Ghana Borders Will Be Partially Closed-Government Discloses. GhBase.com ${ }^{\mathrm{TM}}$, n.d.). On the side of needed finances, the government has set up a Coronavirus Alleviation Programme (CAP) to fund the activities of the fight against corona virus. This fund is internally generated by stakeholders, philanthropists, government agencies and the citizenry (Govt. Seeks to Lower Cap on Stabilization Fund, n.d.). All places marked as hotspots by the GHS have had a restriction on movement with a social distancing requirement and put under observation (Coronavirus Travel Restrictions and Bans Globally: Updating List-The New York Times, n.d.; COVID-19 Updates/Ghana, n.d.). There has been the delivery of coveralls, masks, goggles, non-contact thermometers, gloves, sanitizers and tests kits and 
also there has been receipt of Personal Protective Equipment (PPE) and toolkits from the Jack Ma foundation (COVID-19 Updates/Ghana, n.d.; Xinhua-China, World, Business, Sports, Entertainment, Photos and Video/English.news.cn, n.d.). To better aid and equip the health service, recruitment of additional community health workers and experienced retired but healthy health workers have been employed to offer their expertise to help and control the spread of the disease in the country (Health Ministry to Recruit More Staff for the COVID-19 Fight-Daily Monitor, n.d.). To help ease the social and economic burden of the citizenry there is also a provision by the government to distribute food to the under privileged in society, a relief in the payment of water bills and also a 50\% cut in electricity bill for a section and fully free for another section based on consumption rates (Lockdown Updates-Akufo-Addo Extends Lockdown One More Week-Announces Govt. Will Pay 50\% of Electricity Bills for Ghanaians-GhanaCelebrities.Com, n.d.).

\section{Suggestions to Further Mitigate COVID-19 in Ghana}

Upon careful assessment, it may be said that the negative impact of COVID-19 seems to outweigh the positive because just like most countries, Ghana was not fully equipped and prepared for the pandemic (Economic Impact of COVID-19 on Ghana: What Are the Channels, n.d.). However, to further minimize and control the effect (s) of COVID-19 on the Ghanaian economy and greater good of the country at large certain measures can be put in place in addition to the ones already in place by the government. Such measures would include, but certainly not being limited to the following;

- The masses, especially the uneducated and illiterates should be well educated and brought to date on issues pertaining to COVID-19 and subsequently be guided on how best to stay safe. Bodies of the government like The National Commission on Civic Education (NCCE), Ghana Health Service (GHS) and others alike can grant interviews or issue press releases to bring the masses to date on the need to stay protected. Communicative contents like animations can be designed and aired on various media platform educating on how to properly wash hands, wear masks and others alike.

- The mass media, both electronic and print should now concentrate more on providing education to the citizenry and equally provide psychologically relieving content to help the citizenry maintain a good mental health.

- Equal and adequate attention should be given across the entire nation. Relief items and others alike shouldn't be given only in known regions and cities but equally in the villages and other places that are not always in the limelight like the homeless ones on the streets, prison cells and orphanage homes.

\section{Conclusion}

Covid-19 as a global pandemic has given Ghana its fair share of challenges. Though many good measures are in place it cannot overturn the impact of the 
pandemic overnight. However, this situation has not only come to slow down economic activities and also challenge health care systems and/or services but has equally opened Ghana up to some good and innovative ways to solve its own challenges internally. In conclusion, it can therefore be said that COVID-19 has had and continues to have a huge impact on Ghana both positively and negatively. And upon careful assessment it is without doubt that the negatives impact seems to outweigh the positive. Just like most countries, Ghana was not adequately equipped and prepared for the COVID-19 pandemic. This therefore makes it necessary for the impact on an important sector like trade to be discussed, looked into and the realities spelt out so that good and workable ideas can be used as a resource for information and intellect to help in the face of the pandemic.

\section{Conflicts of Interest}

The authors declare no conflicts of interest regarding the publication of this paper.

\section{References}

(2019). Global Market Outlook Not over until It's Over.

(n.d.) COVID-19 Updates/Ghana.

https://www.ghanahealthservice.org/covid19/archive.php

(n.d.). 404-Thedistin.

(n.d.). 50,000 Enumeration Areas Earmarked for 2020 Population Census-Business Ghana.

(n.d.). Coronavirus Travel Restrictions and Bans Globally: Updating List-The New York Times. https://www.nytimes.com/article/coronavirus-travel-restrictions.html

(n.d.). Coronavirus: Kasapreko Halts Production of Drinks to Produce Hand Sanitizers. https://www.ghanaweb.com/GhanaHomePage/business/Coronavirus-Kasapreko-haltsproduction-of-drinks-to-produce-hand-sanitizers-902056

(n.d.). COVID-19 Heralds Mass Cleanup in Ghanaian Capital/Voice of America-English. https://www.voanews.com/archive/covid-19-heralds-mass-cleanup-ghanaian-capital

(n.d.). Economic Impact of COVID-19 on Ghana: What Are the Channels?

(n.d.). Ghana Borders Will Be Partially Closed-Government Discloses. GhBase.com ${ }^{\mathrm{TM}}$. https://www.ghbase.com/ghana-borders-will-be-partially-closed-government-discloses

(n.d.). Ghana Economy-GDP, Inflation, CPI and Interest Rate. https://www.ghanahealthservice.org/covid19

(n.d.). Ghana GDP Annual Growth Rate/2000-2019 Data/2020-2022 Forecast/Calendar. https://www.ghanahealthservice.org/covid19

(n.d.). Ghana Population (2020)-Worldometer. https://www.worldometers.info/world-population/ghana-population

(n.d.). Govt. Seeks to Lower Cap on Stabilization Fund. https://www.ghanaweb.com/GhanaHomePage/business/Govt-seeks-to-lower-cap-on-S tabilization-Fund-908863

(n.d.). Health Ministry to Recruit More Staff for the COVID-19 Fight-Daily Monitor. 
https://www.monitor.co.ug/News/National/COVID-19-fight-Health-ministry-recruitmore-staff/688334-5495762-13agr35z/index.html

(n.d.). Lockdown Updates-Akufo-Addo Extends Lockdown One More Week-Announces Govt. Will Pay 50\% of Electricity Bills for Ghanaians-GhanaCelebrities. Com. https://www.ghanacelebrities.com/2020/04/10/lockdown-updates-akufo-addo-extends-lo ckdown-one-more-week-announces-govt-will-pay-50-of-electricity-bills-for-ghanaians

(n.d.). Situation Update Worldwide, as of 11 April 2020. https://cn.bing.com/search?q=richardkwartengghana\&qs=n\&form=QBRE\&sp=-1\&pq $=$ richardkwartengghana\&sc $=1-22 \& s k=\& \mathrm{cvid}=\mathrm{E} 55452 \mathrm{C} 3 \mathrm{C} 94844 \mathrm{DEBF} 1 \mathrm{BA} 7 \mathrm{~B} 4309 \mathrm{BD} 7$ $\underline{36}$

(n.d.). What Does COVID-19 Stand for? Meaning of Coronavirus Name-World News-Mirror Online. https://www.mirror.co.uk/news/world-news/what-covid-19-stand-for-21714375

(n.d.). WHO Finally Declares COVID-19 a "Pandemic"/Live Science.

(n.d.). Who-China-Joint-Mission-on-Covid-19-Final-Report. https://www.mirror.co.uk/news/world-news/what-covid-19-stand-for-21714375

(n.d.). Xinhua-China, World, Business, Sports, Entertainment, Photos and Video/English.news.cn. http://www.news.cn/english

Addi, R. A., Benksim, A., Amine, M., \& Cherkaoui, M. (2020). COVID-19 Outbreak and Perspective in Morocco. Electronic Journal of General Medicine, 17, em204. https://www.livescience.com/coronavirus-pandemic-who.html https://doi.org/10.29333/ejgm/7857

Agyekum, C. K., Haifeng, H., \& Amma, A. (2015). Review of China's Trade on the Economic Growth of Ghana. American Journal of Economics, 5, 315-320.

Ayittey, F. K., Ayittey, M. K., Chiwero, N. B., Kamasah, J. S., \& Dzuvor, C. (2020). Economic Impacts of Wuhan 2019-nCoV on China and the World. Journal of Medical Virology, 92, 473-475. https://doi.org/10.1002/jmv.25706

Cooperative, K. I. (2020). 2020 Budget Highlights. November 2019.

Enu, P., Havi, E. D. K., \& Hagan, E. (2013). The Impact of Foreign Trade on Economic Growth in Ghana (1980-2012). International Journal of Academic Research in Economics and Management Sciences, 2, 174-191. https://doi.org/10.6007/IJAREMS/v2-i5/371

GHS (2018). The Health System in Ghana, Facts and Figures (pp. 28-68). Ghana Health Service.

Mathur, M. B., Patel, R. B., Gould, M., Uyeki, T. M., Bhattacharya, J., Xiao, Y., Gillaspie, Y., Chae, C., \& Khazeni, N. (2014). Seasonal Patterns in Human a (H5N1) Virus Infection: Analysis of Global Cases. PLoS ONE, 9, e106171.

https://doi.org/10.1371/journal.pone.0106171

Munthali, G. C., Chidimbah Munthali, G. N., \& Xuelian, W. (2020). Private Bag 201 Luwinga Mzuzu Malawi, MALAWI 2 Yangtze University Nanhuan Road 1th, Jingzhou city, Hubei Province, CHINA 3 Chidimbah Financial Consultants, MALAWI *Corresponding Author: Huaitian07@outlook.com Citation: Munthali GNC, Xuelian W. Covid-19 Ou. Electronic Journal of General Medicine, No. 4, 2516-3507.

Ofori-Atta, K. (2020). 2020 Fiscal Strategy Document.

Ostwald, K. (2014). Ebola, SARS, and the Economies of Southeast Asia.

Qiu, W., Rutherford, S., Mao, A., \& Chu, C. (2017). The Pandemic and Its Impacts. Health, Culture and Society, 9, 1-11. https://doi.org/10.5195/HCS.2017.221 
UNCTAD (2020). The Covid-19 Shock to Developing Countries: Towards a Whatever It Takes Programme for the Two-Thirds of the World's Population Being Left behind.

WHO Ebola Response Team (2016). Special Report after Ebola in West Africa-Unpredictable Risks, Preventable Epidemics. The New England Journal of Medicine, 375, 587-596. https://doi.org/10.1056/NEJMsr1513109 